\title{
Demographic and Social Status of Sporting Bull Rearers and Rearing of Jallikattu Bulls
}

\author{
R. Priyadharsini, A. Gopinathan*, S. M. K. Karthickeyan and P. N. Richard Jagatheesan \\ Department of Animal Genetics and Breeding, Madras Veterinary College, Chennai - 600 \\ 007, Tamil Nadu Veterinary and Animal Sciences University, Tamil Nadu, India \\ *Corresponding author
}

\section{A B S T R A C T}

The study was conducted among 176 sporting bull rearers in Madurai, Trichy, Dindigul and Pudukottai districts who were actively involved in sporting bull rearing. Majority of

\section{Keywords}

Jallikattu, Sporting bull, Socioeconomic profile

Article Info

Accepted:

22 July 2019

Available Online:

10 August 2019 the sporting bull rearers were in the age group of less than 35 years (38.64 per cent) followed by 36 to 45 years ( 31.25 per cent) and more than 45 years (30.11 per cent) and they were illiterate ( 75.57 per cent) and mostly belonging to Hindu religion (77.27 per cent). Among bull rearers, 63.64 percent of the respondents belonged to backward community followed by most backward ( 26.14 percent) community and scheduled castes (9.60 percent). The data depicted that more than half of the respondents (55.11 per cent) were rearing the sporting bulls as an ancestral legacy for several decades. The bull rearers selected the bull calves based on alertness ( 24.21 per cent), body conformation (21.56 per cent) and whirls (19.96 per cent). Most of the bull rearers ( 85.22 per cent) believed that training was essential and their choices were swimming (30.50 per cent), vaadi (22.91 per cent) and hooking the soil by horns (17.98 per cent) for sporting bulls. The findings of this study indicated that it is an age-old traditional sporting event; even though there was no income from these sporting bulls they reared because of their ancestral practice.

\section{Introduction}

In India, Tamil Nadu is one of the major agrarian states and bestowed with four important recognized indigenous cattle breeds viz. Bargur, Kangayam, Pulikulam and Umblachery; and all of them are an integral part of agriculture and played major role for sustainable livelihood to rural farmers in the backdrop of varied climatic conditions. Some of these breeds were predominantly used for sporting events especially in jallikattu to recreate the rural farmers at the time of festival season (pongal) to worship the god for better monsoon and harvest. Among the districts in Tamil Nadu, Madurai, Sivagangai, Trichy, Dindigul and Pudukottai districts are known for "Bull baiting or Jallikattu" sporting event. These sporting events are age-old traditional and they had been mentioned in ancient Tamil literatures and epics. Documentation of sporting bulls and their cultural association with the folk had been carried out in ancient times by the scholars of Tamil and animal lovers. However, the investigation on socio-economic attributes of 
bull rearers and their managing practices for rearing of sporting bulls have not been attempted so far. Hence, this study was planned to assess the socio-economic status of sporting bull rearers and their rearing of sporting bull in Tamil Nadu.

\section{Materials and Methods}

Information pertaining to demographic and social status of sporting bull rearers and their source of purchase, selection, training of bull calves and participation in sporting events were collected. The data were collected from well organized interview schedule along with questionnaire from the sample size of 176 bull owners present in 33 villages of Madurai, Trichy, Pudukottai and Dindigul districts. All the collected information were computerized and analysed by using appropriate statistical techniques.

\section{Results and Discussion}

The results of primary data pertaining to status of bull rearers, breeding, feeding and participation in sporting events are given in Table 1.

\section{Profile of the bull rearers}

\section{Age of the bull rearers and education status}

In this study, majority of the sporting bull rearers were in the age group of less than 35 years (38.64 per cent) followed by 36 to 45 years (31.25 per cent) and more than 45 years (30.11 per cent); and it gives a fair idea about age of the bull rearers who play a crucial role as they inherited the traditional knowledge of this sporting event from their ancestors and inculcate the same among the younger generation for succeeding years, since it was reflected almost all age groups showed interest to rear the sporting bulls. A greater part of respondents were illiterate (75.57 per cent).
This might be due to the fact that the respondents were engaged in agriculture and livestock rearing early in life and they gave up the primary education.

\section{Religion, community and annual income}

Majority of sporting bull rearers belongs to Hindu (77.27 per cent) and Christian (22.73 per cent) religions. 22.73 per cent of christian farmers belong to Trichy district only and they reared and conducted this sporting event. Among bull rearers, 63.64 percent of the respondents belonged to backward community, most backward community (26.14 percent), scheduled castes (9.60 percent) and scheduled tribe (0.06 per cent). Most of the bull farmers belonging to backward community to rear Pulikulam cattle as their ancestral occupation, which is in agreement with Thesinguraja et al., (2017) but contrast to his finding none of the respondent belong to SC and ST category. Most of the bull rearers had annual income of eighty five thousand to one lakh sixty five thousand (59.10 per cent), which is in agreement with the findings of Thesinguraja et al., (2017) in socio-economic status of Pulikulam cattle rearers.

Number of sporting animals reared and number of individuals needed to rear a sporting bull

In this study, bull rearers were having one (58.52 per cent), two (29.54 per cent) and more than two bulls (11.94 per cent) in their possession. The less number of sporting bull reared by a farmer might be due to high feeding cost, time consuming training process and management problems due to ferociousness of sporting bull.

Number of individuals needed to rear a sporting bull was one (28.98 per cent), two (37.50 per cent), three (28.41 per cent) and more than three (5.11 per cent). This might be 
due to make them savage towards strangers, kept apart separately and fed by one or two family members only and similar findings also reported by Pattabhiraman (1962).

\section{Reasons and experience for rearing sporting bulls}

The data depicted that more than half of the respondents (55.11 per cent) were rearing the sporting bulls as an ancestral legacy for several decades followed by more than onethird of respondents from their childhood (34.10 per cent) and remaining were beginners (Figure 1). About 38.64 and 31.25 per cent of bull rearers had the experience of bull rearing from 10 to 20 and more than 20 years respectively. It depicted the sporting bull rearing had been in the cultural living system of agrarian community since ancient days and it also unfolding the reason behind the existence of this breed still today, i.e. participation of stakeholders for conservation of indigenous breeds as they are bestowed with endurance and aggressiveness, which is suitable for this sporting event.

As there is dearth of literature about profile of sporting bull rearers in India and particularly in Tamil Nadu, the result obtained in the present study could not be compared.

\section{Profile of the sporting bulls}

\section{Source and age at purchase}

As mentioned in Table 1, the bulls were purchased from reputed livestock market (shandy) in nearby areas (51.70 per cent), since, they were so many livestock markets selling native breeds in Madurai, Sivagangai, Dindigul and Trichy districts and followed by procurement from other cattle herds (27.84 per cent). Some owners preferred to select the calf in cattle herds itself by observing the social activities of male calves, sire and dam performance in herds. Most preferred age to purchase the bull calves was at six months to one year (52.27 per cent).

\section{Optimum age for selection and training to sporting bulls}

Majority of the respondents followed the practice of selecting the bull calves at six months of age (68.75 per cent) and started giving training at the age of six months $(60.23$ per cent) itself.

This might be due to ease to give training to a calf and cost of the animal was economical to purchase; which is in agreement with the report of Nisha (2016) who stated that bulls were sold and trained for bull baiting at six to seven months of age.

\section{Selection criterion for sporting bulls}

From this study, bull rearers selected the bull calves based on vigour and exuberance (24.21 per cent), body conformation (21.56 per cent) and whirls (19.96 per cent); which were represented in Figure 2 and these observations concurred with the findings of Ezhilvendan (2013), who documented selection of bull calves based on bounce and vivacity for sporting purpose in Tamil Nadu.

Hence, presence of aggression in the sporting bulls results from early selection of bull calves based on alertness and conformation.

Among the respondents, 19.96 per cent of bull rearers gave importance to whirls present on the forehead and back of the bull calves, as a selection criterion for sporting event.

It might be due to their indigenous traditional knowledge inherited from their ancestors that whirls in those areas indicate aggressiveness. Ancestors gave names to each whirls present in the body of bull calves. 
Table.1 Demographic and socio-economic attributes of sporting bull rearers and rearing practices of sporting bulls

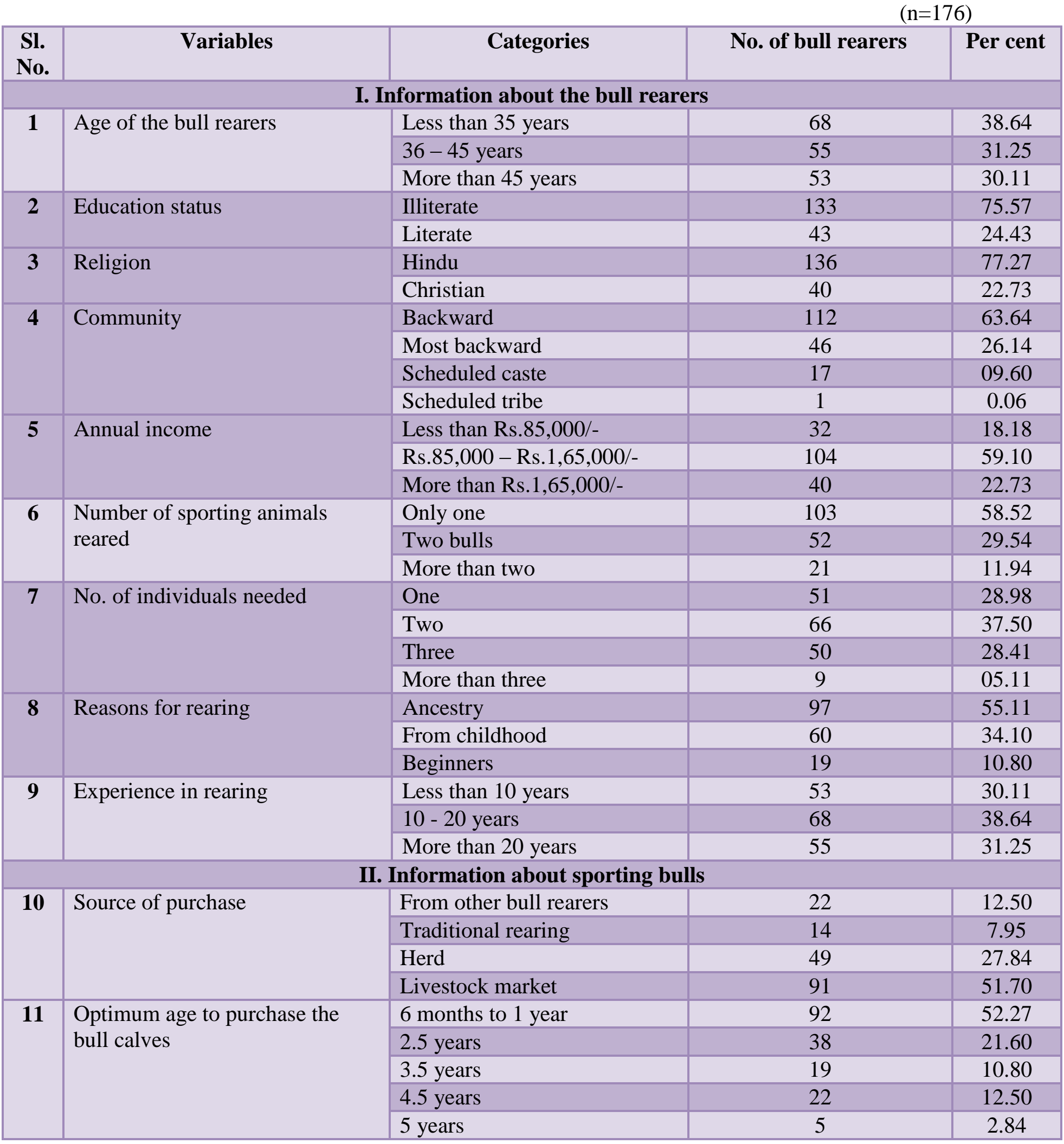




\begin{tabular}{|c|c|c|c|c|}
\hline $\begin{array}{l}\text { Sl. } \\
\text { No. }\end{array}$ & Variables & Categories & $\begin{array}{l}\text { No. of bull } \\
\text { rearers }\end{array}$ & Per cent \\
\hline \multirow[t]{3}{*}{12} & \multirow[t]{3}{*}{ Optimum age for selection } & 6 month & 121 & 68.75 \\
\hline & & 2.5 years & 51 & 28.98 \\
\hline & & 3.5 years & 4 & 2.27 \\
\hline \multirow[t]{2}{*}{13} & \multirow[t]{2}{*}{ Training is essential } & Yes & 150 & 85.22 \\
\hline & & No & 26 & 14.78 \\
\hline \multirow[t]{3}{*}{14} & \multirow[t]{3}{*}{ Optimum age to start training } & 6 month & 106 & 60.23 \\
\hline & & 2.5 years & 61 & 34.66 \\
\hline & & 3.5 years & 9 & 5.11 \\
\hline \multirow[t]{3}{*}{15} & \multirow[t]{3}{*}{ Duration of training per day } & 15 minutes & 62 & 35.23 \\
\hline & & 30 minutes & 89 & 50.57 \\
\hline & & No specific timings & 25 & 14.20 \\
\hline \multirow[t]{2}{*}{16} & \multirow[t]{2}{*}{ Response to training } & Good & 143 & 81.25 \\
\hline & & Poor & 33 & 18.75 \\
\hline \multirow[t]{4}{*}{17} & \multirow[t]{4}{*}{ Frequency of training } & Weekly once & 97 & 55.11 \\
\hline & & Monthly once & 19 & 10.80 \\
\hline & & Monthly twice & 36 & 20.45 \\
\hline & & No specific frequency & 24 & 13.63 \\
\hline \multirow[t]{2}{*}{18} & \multirow[t]{2}{*}{ Difficulties during training } & Yes & 16 & 9.10 \\
\hline & & No & 160 & 90.90 \\
\hline \multirow[t]{4}{*}{19} & \multirow{4}{*}{$\begin{array}{l}\text { Age at first participation in the } \\
\text { sporting event }\end{array}$} & Less than 2.5 years & 72 & 40.91 \\
\hline & & 2.5-3.5 years & 91 & 51.70 \\
\hline & & $3.5-4.5$ years & 6 & 3.41 \\
\hline & & More than 5 years & 7 & 3.98 \\
\hline \multirow[t]{3}{*}{20} & \multirow[t]{3}{*}{ Sporting life of bull } & Less than 8 years & 81 & 46.02 \\
\hline & & $8-10$ years & 51 & 28.98 \\
\hline & & More than 10 years & 44 & 25.00 \\
\hline \multirow[t]{3}{*}{21} & \multirow{3}{*}{$\begin{array}{l}\text { Utility of bull after sporting } \\
\text { life }\end{array}$} & Keeping up to death & 134 & 76.14 \\
\hline & & Natural service & 40 & 22.73 \\
\hline & & Slaughter & 2 & 1.14 \\
\hline \multirow[t]{3}{*}{22} & \multirow[t]{3}{*}{ Disposal of losing bulls } & Keeping up to death & 101 & 57.39 \\
\hline & & Sold to others & 73 & 41.48 \\
\hline & & Slaughter & 2 & 1.14 \\
\hline
\end{tabular}




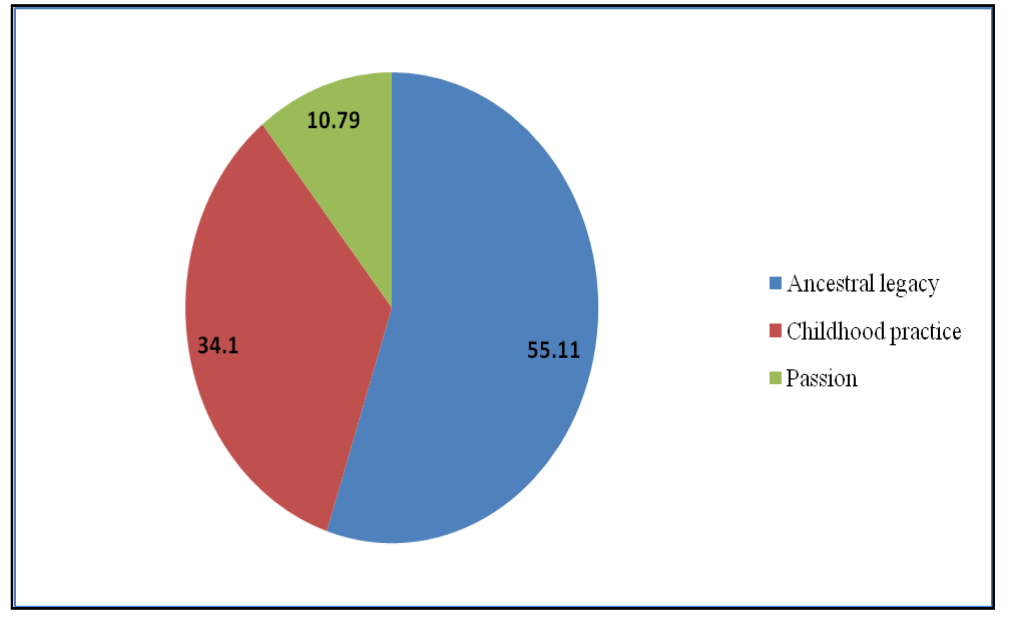

Figure 1 Reasons for rearing sporting bulls (in per cent)

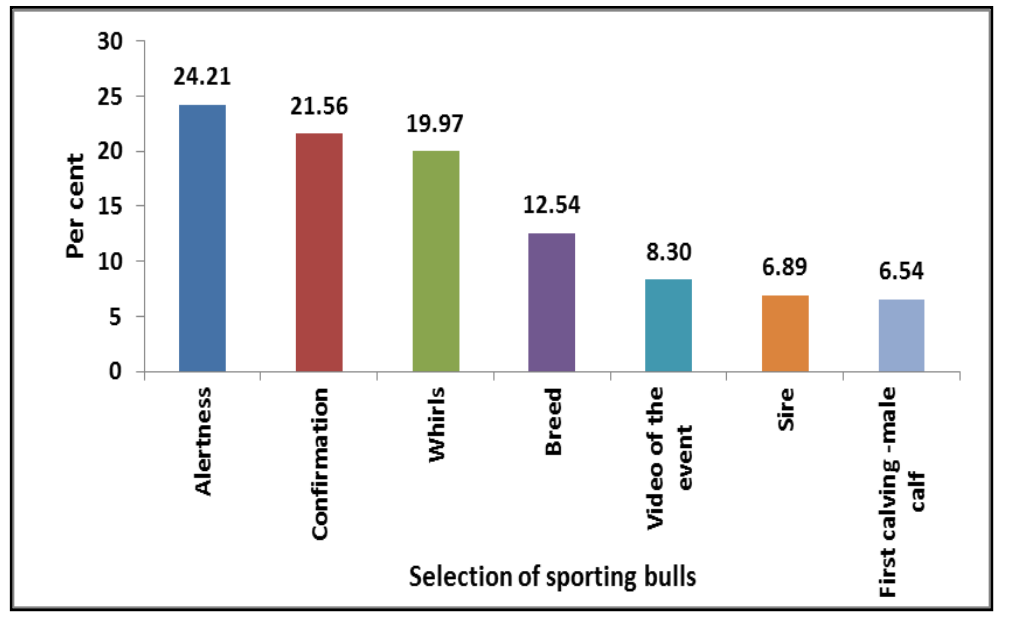

Figure 2 Selection criteria for sporting bulls

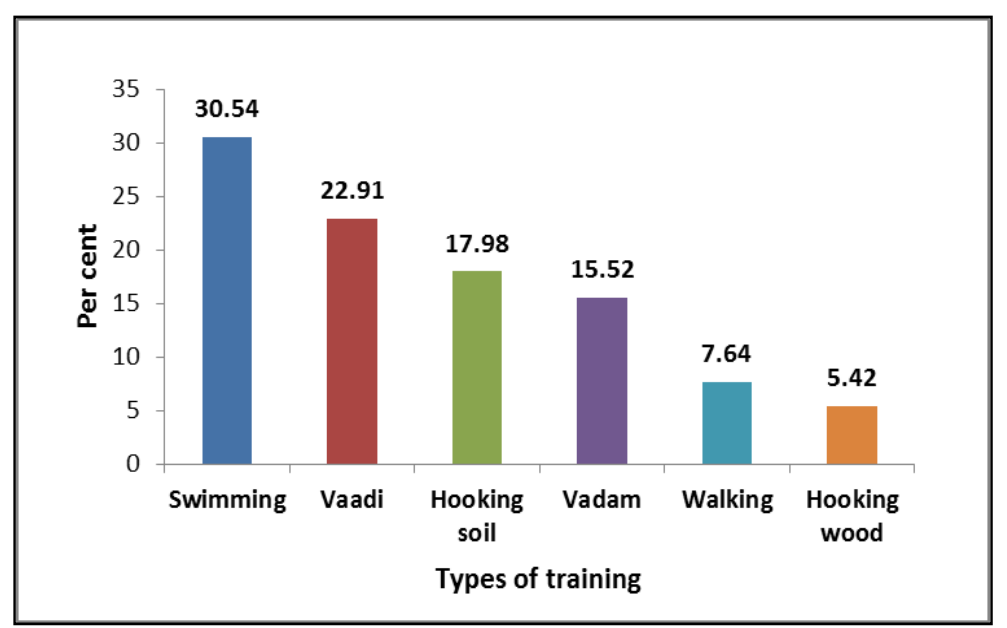

Figure 3 Types of training to sporting bulls 


\section{Type of training to sporting bulls}

Majority of bull rearers preferred to give training like swimming (30.50 per cent), vaadi (22.91 per cent) and hooking the soil (17.98 per cent) to sporting bulls which coincided with the reports published in English daily (The Hindu, dated 14/01/2018) and report of Ezhilvendan (2013). From the data collected through the questionnaire, it was understood that swimming was practised in bulls to prevent respiratory distress in the sporting arena and strengthening the legs of sporting bulls. Vaadi was used to improve gesture and language training, and whistle sound by a gang of bull tamers towards sporting bullsto increase aggression behavior. Hooking the soil was practised to sharpen their horns and used to threaten the bull tamers in sporting arena and they were illustrated in Figure 3. Majority (85.22 per cent) of the bull owners opined that training was essential and these might help the bulls to show aggression in the sporting event.

With respect to duration of training, one half (50.57 per cent) of the bull rearers were given training to sporting bulls atleast 30 minutes to and nearly one half (55.11 per cent) of the bull rearers were giving training for weekly once.

\section{Difficulties during training}

The respondents observed that no obscurity during training of bulls ( 90.90 per cent) and response to the training was good (81.25 per cent).

\section{Age at first participation in sporting event}

Majority of the sporting bulls (92.6 per cent) were allowed for the first time in sporting event, when they were below 3.5 years of age and their sporting life was less than eight years of age (46.02 per cent).

\section{Utility and disposal of bull after sporting life}

After their sporting life, the bulls were reared either till their death (76.14 per cent) or for natural service (22.73 per cent) or sold for slaughter (1.14 per cent).Even there was no utility of bull after sporting life they rearing sporting bull because of ancestral practice, love towards the bull and for prestige.

Nearly one-half (57.39 per cent) of the bull rearers were not disposing the sporting bulls, they keeping the bulls in home till their death. This indicated that majority of the bull rearers worship the bull as equal to god and treat them as one of the family member till its death. About 22.73 per cent of bull rearers gave the winning bull as a gift to their ancestral god and it had been considered as a "Temple Bull"; though, it was not tied, but allowed to roam and wander (as a dominant bull) and consequently sire the indigenous cows naturally in the nearby villages, thereby promoting the genetic variability of the population and prevent the indigenous breeds from extinction in their breeding tract.

Bull rearers sold their winning bulls (41.48 per cent) at exorbitant price to needy bull rearers and now-a-days, it has been one of the value added bull enterprises for them. Only in Madurai, Trichy and Dindigul districts, the male calves are not sold for slaughter, rather reared for sporting events.Even after the death of sporting bull, they buried in back of their home or their own land itself built the temple and worshiped as god. From this study, it was observed that the bull rearers are rearing their bull calves only based on interest and enthusiasm, without any financial assistance. This event is an ancient and traditional sporting event for livestock keepers and agrarian community to safeguard the livestock wealth in the rural areas for future generations. 


\section{References}

Ezhilvendan, 2013.Valour in Jellicut. $1^{\text {st }}$ Edn., Ezhilvendan pathipagam, Tuticorin.

Nisha, P., Sethu, S. and Thilakar, P (2016). Community rearing system of Pulikulam cattle: A case study in Tamil Nadu, India. Indian Vet. J., 93(1): 8284.

Pattabhiraman, D., 1962. Breeds of Cattle in
Tamilnad, Madras. pp. 20-24. The Hindu, dated 14/01/2018(English daily) Thesinguraja, S., Mathialagan, P., Thilakar, P., Devendran, $\mathrm{P}$ and Palanichamy, V (2017). Socio-economic profile of Pulikulam cattle rearers in Madurai and Sivaganagai districts of Tamil Nadu, India.Int. J. Curr. Microbio. App. Sci., 6(12): 424-429.

\section{How to cite this article:}

Priyadharsini R., A. Gopinathan, S. M. K. Karthickeyan and Richard Jagatheesan P. N. 2019. Demographic and Social Status of Sporting Bull Rearers and Rearing of Jallikattu Bulls. Int.J.Curr.Microbiol.App.Sci. 8(08): 2799-2806. doi: https://doi.org/10.20546/ijcmas.2019.808.322 